\title{
Metformin causes cancer cell death through downregulation of p53-dependent differentiated embryo chondrocyte 1
}

\author{
Shu-Man Hsieh Li ${ }^{1}$, Shu-Ting Liu', Yung-Lung Chang ${ }^{1}$, Ching-Liang Ho ${ }^{2^{*}}$ and Shih-Ming Huang ${ }^{1 *}$ (D)
}

\begin{abstract}
Background: Metformin is the most commonly used first-line medicine for type II diabetes mellitus. Acting via AMP-activated protein kinase, it has been used for more than 60 years and has an outstanding safety record. Metformin also offers protection against cancer, but its precise mechanisms remain unclear.
\end{abstract}

Methods: We first examined the cytotoxic effects of metformin in the HeLa human cervical carcinoma and ZR-75-1 breast cancer cell lines using assays of cell viability, cleaved poly-ADP-ribose polymerase, and Annexin V-fluorescein isothiocyanate apoptosis, as well as flow cytometric analyses of the cell cycle profile and reactive oxygen species (ROS). We later clarified the effect of metformin on p53 protein stability using transient transfection and cycloheximide chase analyses.

Results: We observed that metformin represses cell cycle progression, thereby inducing subG1 populations, and had induced apoptosis through downregulation of p53 protein and a target gene, differentiated embryo chondrocyte 1 (DEC1). In addition, metformin increased intracellular ROS levels, but N-acetyl cysteine, a ROS scavenger, failed to suppress metformin-induced apoptosis. Further results showed that metformin disrupted the electron transport chain and collapsed the mitochondrial membrane potential, which may be the cause of the elevated ROS levels. Examination of the mechanisms underlying metformin-induced HeLa cell death revealed that reduced stability of p53 in metformin-treated cells leads to decreases in DEC1 and induction of apoptosis.

Conclusion: The involvement of DEC1 provides new insight into the positive or negative functional roles of p53 in the metformin-induced cytotoxicity in tumor cells.

Keywords: Metformin, p53, Apoptosis, Reactive oxygen species, DEC1

\section{Background}

The biguanide metformin is a first-line oral anti-hyperglycemic agent prescribed to nearly all newly diagnosed type II diabetes mellitus patients. Metformin also appears to have clinical benefits in other diseases, including diabetic nephropathy, stage III chronic kidney disease, and the cardiovascular complications associated with diabetes, such as cardiac hypertrophy and myocardial infarction [1, 2]. Although metformin has been used in Europe since 1957, the precise molecular mechanisms

\footnotetext{
* Correspondence: 02241@ndmctsgh.edu.tw; shihming@ndmctsgh.edu.tw 2Division of Hematology/Oncology, Department of Medicine, Tri-Service General Hospital, National Defense Medical Center, Taipei City 114, Taiwan, Republic of China

${ }^{1}$ Department of Biochemistry, National Defense Medical Center, Taipei City 114, Taiwan, Republic of China
}

by which it mitigates diabetes are sill not fully understood. Results from an increasing number of studies suggest metformin works in the liver. Metformin enters liver cells primarily via organic cation transporter- 1 and then suppresses mitochondrial complex I, which leads to a decrease in ATP levels and a rise in AMP levels [3]. The resultant change in the AMP/ATP ratio leads to activation of AMP-activated protein kinase (AMPK), which suppresses fatty acid synthesis and gluconeogenesis, and exerts insulin sensitizing effects [4].

Several studies indicate that metformin also exerts protective effects against inflammation, age-related pathologies, and cancer [2, 5-8]. Retrospective and prospective evidence suggests taking metformin is related to a decline in the incidences of various cancers, including 
hepatocellular carcinoma, pancreatic cancer, and colon cancer in diabetic patients [2, 7-10]. At present, there are at least 3860 articles listed in PubMed that are related to the study of metformin in cancer. Consequently, there are large amounts of both in vitro and in vivo data on the antitumor effects of metformin. Metformin is able to not only reduce insulin but also inhibit the mammalian target of rapamycin (mTOR) signaling pathway, which makes it an especially appealing target for evaluating metabolism unique to tumor cells, such as the Warburg effect $[2,9]$. It has been proposed that the cancer preventive actions of metformin involve four components: 1) cancer stems cells, 2) microRNAs (miRs), 3) epithelial-to-mesenchymal transition (EMT), and 4) cellular senescence $[9,11,12]$. But as with diabetes, details of the mechanisms by which metformin acts against cancer remain unclear.

p53 is a well-known tumor suppressor gene that plays a vital role in about $50 \%$ of human cancers $[13,14]$. At the premalignant tumor stage, senescence can be triggered normally by stressors such as DNA damage, oncogenes, and oxidative damage. In response to such stresses, p53 is activated and induces transcription of a variety of target genes to cause cells change their phenotypes from DNA repair to apoptosis and senescence [14, 15]. It appears, for example, that p53 transcriptional regulation of components of both the extrinsic (via a caspase cascade) and intrinsic (via the mitochondria) pathways serves as an apoptosis inducer $[16,17]$. Moreover, p53 is also able to promote apoptosis through transcriptional induction of redox-related genes to generate reactive oxygen species (ROS), which in turn cause oxidative degradation of mitochondrial components and cell death $[16,18,19]$. Notably, metformin reduces the abundance of p53 in cases of hepatosteatosis, but enhances p53 stability via USP7 in esophageal cancer [20, 21]. Consequently, there is a need to confirm the availability and function of p53 in cancers treated with metformin in our working system. In the present study, therefore, we examined the cytotoxic effects of metformin in two cancer cell lines, clarifying its effects on apoptosis, ROS generation, mitochondrial function, differentiated embryo chondrocyte 1 (DEC1) expression, and p53 protein stability. Our findings provide new information for the potential reposition of metformin in the treatment of cancer.

\section{Methods}

\section{Cell culture and reagents}

HeLa cells were cultivated in Dulbecco's modified Eagle's medium (DMEM) supplemented with 10\% fetal bovine serum (FBS) and 1\% penicillin-streptomycin (Invitrogen, MA, USA). ZR-75-1 breast cancer cells were cultivated in Roswell Park Memorial Institute (RPMI) 1640 medium supplemented with 10\% FBS and 1\% penicillin-streptomycin
(Invitrogen). Actinomycin D (Act D), cycloheximide (CHX), 2',7-dichlorofluorescein diacetate (DCFH-DA), hydrogen peroxide $\left(\mathrm{H}_{2} \mathrm{O}_{2}\right)$, metformin, MG132, $N$-acetyl cysteine (NAC), propidium iodide (PI), and thiazolyl blue tetrazlium bromide (MTT) were obtained from Sigma Aldrich (MO, USA). Pifithrin- $\alpha$ and Z-VAD-FMK was from Enzo (CA, USA).

\section{Cell survival analysis}

Cells were seeded into 24-well culture plates and incubated for 1 day, after which they were exposed to different concentrations of metformin in fresh DMEM or RPMI 1640 for the indicated periods of time. After adding MTT solution $(0.5 \mathrm{mg} / \mathrm{ml}$ in phosphate buffered saline, PBS) to each well, the cells were incubated for $1 \mathrm{~h}$ at $37^{\circ} \mathrm{C}$. Dimethylsulfoxide (DMSO; $200 \mu \mathrm{l}$ ) was then added, and the absorbance at $570 \mathrm{~nm}$ and $620 \mathrm{~nm}$ each was measured using an ELISA plate reader (Multiskan EX, Thermo, MA, USA). The control group containing cells cultured in medium only was defined as $100 \%$ cell survival.

\section{Western blotting}

Cells were lysed at $4{ }^{\circ} \mathrm{C}$ in lysis buffer $(100 \mathrm{mM}$ Tris- $\mathrm{HCl}$ of $\mathrm{pH}$ 8.0, $150 \mathrm{mM} \mathrm{NaCl}, 0.1 \%$ SDS, and $1 \%$ Triton X-100). Proteins in the lysate were separated by SDS-PAGE, transferred onto polyvinylidene difluoride membranes (Millipore, MA, USA), and probed using antibodies against $\alpha$-actinin (ACTN), cyclin D1, HSP90 $\alpha / \beta$, p53(Santa Cruz Biotechnology, CA, USA), caspase 3, cyclin B1, EGFR, p-Histone H3 (phosphorylation at Ser 10, H3P), cleaved poly-ADP-ribose polymerase (cPARP) (Cell Signaling, MA, USA), and DEC1 (Bethyl Laboratory, TX, USA).

\section{Fluorescence-activated cell sorting (FACS), cell cycle profiles, apoptosis, and ROS analysis}

Cells were fixed in 70\% ice-cold ethanol and stored at $30^{\circ} \mathrm{C}$ overnight, after which they were washed with ice-cold PBS supplemented with 1\% FBS twice and stained with PI solution $(5 \mu \mathrm{g} / \mathrm{ml}$ PI in PBS, $0.5 \%$ Triton $\mathrm{X}-100$, and $0.5 \mu \mathrm{g} / \mathrm{ml}$ RNase A) for $30 \mathrm{~min}$ at $37^{\circ} \mathrm{C}$ in the dark. The cell cycle distribution was then evaluated based on cellular DNA content using FACS.

The incidence of apoptosis (early and late stages) and necrosis was assessed using a fluorescein isothiocyanate (FITC)-Annexin V Apoptosis Detection Kit (BD Biosciences, CA, USA) according to the manufacturer's protocol.

The fluorescent marker DCFH-DA was used to determine intracellular ROS levels. Cells were incubated for $20 \mathrm{~h}$ with the indicated concentrations of metformin or with $\mathrm{H}_{2} \mathrm{O}_{2}$ as a positive control. Living cells were then stained with DCFH-DA $(20 \mu \mathrm{M})$ for $40 \mathrm{~min}$ at $37^{\circ} \mathrm{C}$ and harvested. After washed once with PBS, the cells were 
evaluated using a FACSCalibur flow cytometer and Cell Quest Pro software (BD Biosciences).

\section{Oxygen consumption rate (OCR)}

The cellular OCR was detected using an XF24 bioenergetic assay according to the manufacturer's protocol (Seahorse Bioscience, Billerica, MA, USA). In brief, HeLa cells were seeded onto an XF24 microplate in DMEM supplemented with 5\% FBS. They were then incubated for 2 days, after which the medium was replaced with sodium bicarbonate-free DMEM supplemented with $1 \%$ FBS. The OCR was measured at a steady state, after which the machine sequentially added the standard samples $(0.5 \mu \mathrm{M}$ and $1 \mu \mathrm{M})$, oligomycin $(1 \mu \mathrm{M})$, carbonyl cyanide 4-[trifluoromethoxy] phenylhydrazone (FCCP; $1 \mu \mathrm{M})$ and a mixture of rotenone $(1 \mu \mathrm{M})$ and myxothiazol $(1 \mu \mathrm{M})$ into the wells to obtain the maximal and non-mitochondrial respiration rates.

\section{Mitochondrial membrane potential analysis}

Mitochondrial potential was measured using a $\mathrm{BD}^{\text {тм }}$ MitoScreen Flow Cytometry Mitochondrial Membrane Potential Detection Kit (BD Biosciences) according to the manufacturer's protocol. Briefly, HeLa cells were incubated for $18 \mathrm{~h}$ in a 6-cm culture plate and treated with metformin. The cells were then trypsinized and pelleted by centrifugation at $1000 \mathrm{rpm}$, after which the cells were resuspended in PBS and counted, which confirmed there were fewer than $1 \times 10^{6}$ cells per ml. The cells were then stained with JC-1 dye $\left(5,5^{\prime}, 6,6^{\prime}\right.$-tetrachloro- $1,1^{\prime}, 3,3^{\prime}$-tetraethylbenzimi-dazolylcarbocyanine iodide) for 10$15 \mathrm{~min}$ at $37^{\circ} \mathrm{C}$ in a $\mathrm{CO}_{2}$ incubator. The fluorescence intensity of the JC-1 was evaluated flow cytometrically. The excitation wavelength was $488 \mathrm{~nm}$, while emission wavelengths of $530 \mathrm{~nm}$ (FL1-H channel) and $580 \mathrm{~nm}$ (FL2-H channel) were used to detect the JC-1 monomer and aggregates, respectively.

\section{Plasmids and transfection}

$D E C 1$ construct was produced by inserting the full-length polymerase chain reaction (PCR) product into pEGFP vector using the SacI-EcoRI restriction sites. The pSG5.HA.p53 expression vector was constructed as described previously [22]. jetPEI (PolyPlus-transfection, France) reagent was used according to the manufacturer's instructions to deliver the plasmids into cells cultivated in 6-well plates. The total amount of DNA in each well was adjusted to the same level by adding empty vector.

\section{Subcellular cytoplasmic, membrane, and nuclear extract preparations}

HeLa cells were cultivated in $100-\mathrm{mm}$ culture dishes and incubated under the indicated conditions. Cytoplasmic, membrane and nuclear extracts were separated using a Subcellular Protein Fractionation Kit for Cultured Cells according to the manufacturer's protocol (Thermo Fisher Scientific, MA, USA). For the cytoplasmic fraction, cells were lysed in Cytoplasmic Extraction buffer (CEB) at $4{ }^{\circ} \mathrm{C}$, after which the cytoplasmic extract (supernatant) was acquired by centrifugation $\left(14,000 \times g, 15 \mathrm{~min}, 4^{\circ} \mathrm{C}\right)$. For the membrane fraction, CEB-treated pellets were lysed in Membrane Extraction buffer (MEB) at $4{ }^{\circ} \mathrm{C}$, and the membrane extract (supernatant) was acquired by centrifugation $\left(14,000 \times g, 15 \mathrm{~min}, 4^{\circ} \mathrm{C}\right)$. For the nuclear fraction, MEB-treated pellets were lysed in Nuclear Extraction buffer at $4^{\circ} \mathrm{C}$, and nuclear extract (supernatant) was acquired by centrifugation $\left(14,000 \times g, 15 \mathrm{~min}, 4^{\circ} \mathrm{C}\right)$.

\section{Fluorescence microscopy}

HeLa cells in 6-well culture plates were cultivated in DMEM supplemented with $10 \%$ FBS and $1 \%$ penicillin-streptomycin. After transfection with pEGFP.DEC1 for $5 \mathrm{~h}$, a fluorescence microscope (Model DMURE2, Leica, Wetzlar, Germany) was used to observe cells expressing the encoded proteins, and Image-Pro ${ }^{\circledR}$ Plus software (Media-cybernetics, MD, USA) was utilized to process the images, as previously described [23].

\section{Reverse transcription-polymerase chain reaction (RT-PCR)}

Total RNA was obtained using the TRIzol (Thermo Fisher Scientific) reagent according to the manufacturer's protocol, after which $1 \mu \mathrm{g}$ of the total RNA was reverse transcribed using MMLV reverse transcriptase (Epicentre Biotechnologies, WI, USA) for $60 \mathrm{~min}$ at $37^{\circ}$ C. A Veriti Thermal Cycler (Applied Biosystems, CA, USA) was utilized to run the PCR reactions. The PCR primers used were as follows: for GAPDH, 5'-CTTC ATTGACCTCAACTAC-3' (forward) and 5'-GCCA 'TCCACAGTCTTCTG-3' (reverse); for p53, 5' -GATG AAGCTCCCAGAATGCCAGAG-3' (reverse) and 5' -GAGTTCCAAGGCCTCATTCAGCTC-3' (reverse).

\section{DEC-1 mRNA interference}

$D E C$-1- and LUC-shRNA-containing lentiviral vectors were purchased from the National RNAi Core Facility (Academia Sinica, Taiwan, ROC). HeLa cells were infected with the indicated retroviruses or lentiviruses in selection medium containing $2 \mathrm{mg} / \mathrm{ml}$ polybrene. Forty-eight hours after infection, cells were treated with $8 \mathrm{mg} / \mathrm{ml}$ puromycin to select for a pool of puromycin-resistant clones. The silencing efficacy was verified by Western blot assay.

\section{Statistical analysis}

Student's t-test was used to compare the difference of apoptotic stages and cell viability by indicted agents. Values of $P<0.05$ were considered significant. 


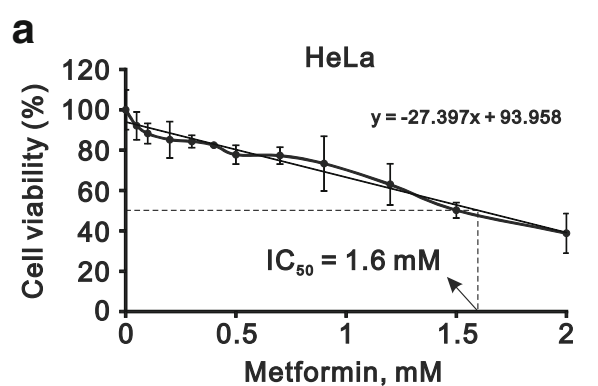

C

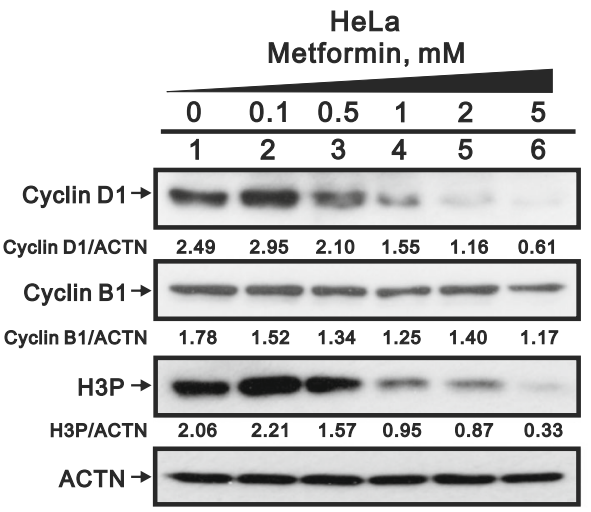

b

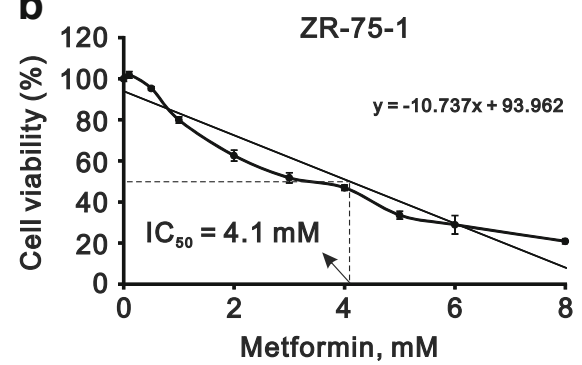

ZR-75-1

Metformin, $\mathrm{mM}$
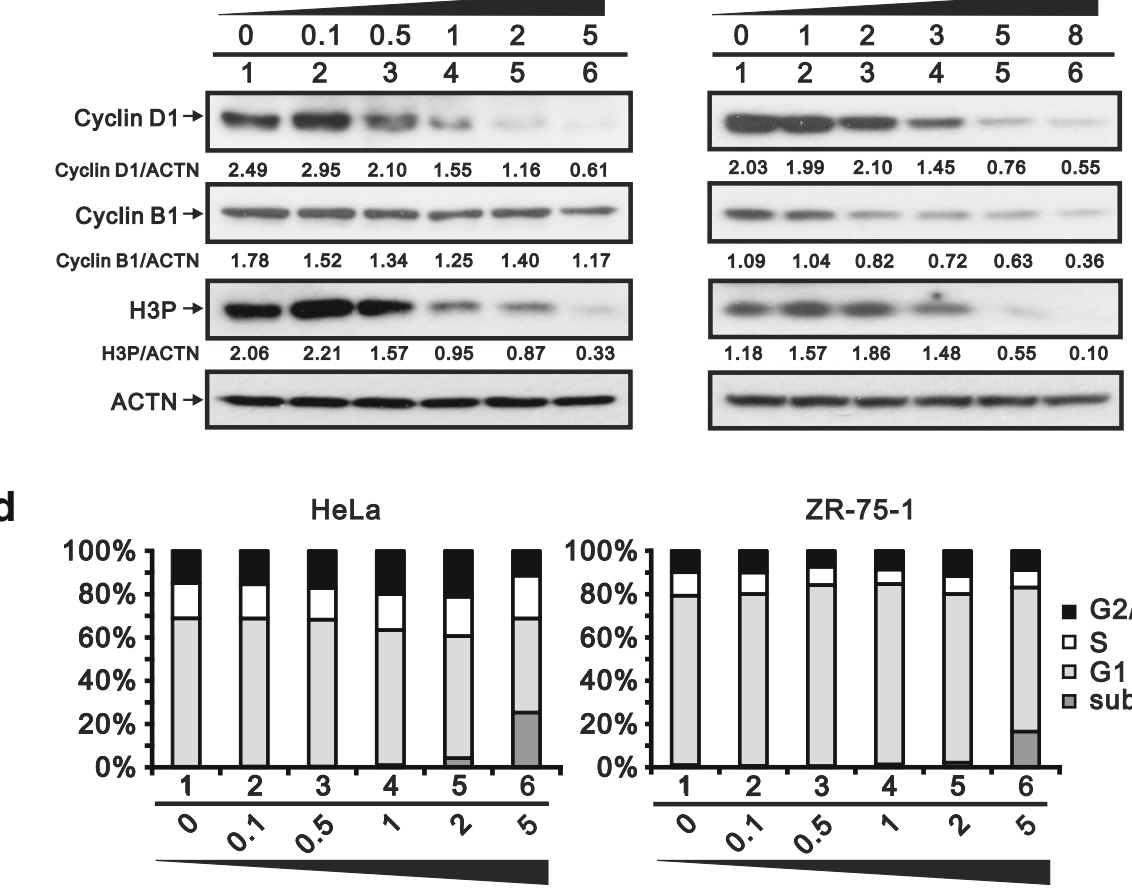

Metformin, $\mathrm{mM}$
ZR-75-1

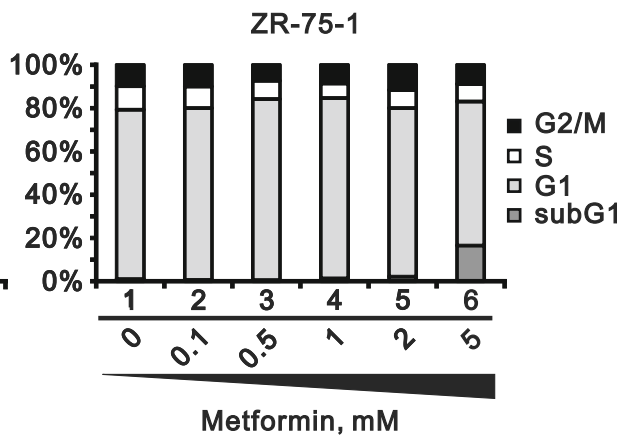

Fig. 1 Cytotoxicity of metformin in HeLa and ZR-75-1 cells. a and $\mathbf{b}$ HeLa cells (a) and ZR-75-1 (b) cells were treated with the indicated concentration of metformin for $35 \mathrm{~h}$ and $70 \mathrm{~h}$, respectively. Cell viability was measured using the MTT method. c HeLa and ZR-75-1 cells were incubated with indicated concentration of metformin for $20 \mathrm{~h}$ and $25 \mathrm{~h}$, respectively. Cell lysates were subjected to western blot analysis using antibodies against cyclin D1, cyclin B1 and H3P. ACTN was the protein loading control. The protein levels of cyclin D1, cyclin B1 and H3P after normalization with the loading control protein ACTN are presented as fold change. $\mathbf{d}$ HeLa and ZR-75-1 cells were incubated with the indicated concentration of metformin for $30 \mathrm{~h}$ and $57 \mathrm{~h}$, respectively. The cells were then subjected to flow cytometric cell cycle profile analysis. The results are representative of three independent experiments

\section{Results}

\section{Metformin reduces cancer cell viability}

We found that metformin reduced cell viability in the HeLa cervical carcinoma and ZR-75-1 breast cancer cell lines, exhibiting IC50s of $1.6 \mathrm{mM}$ and $4.1 \mathrm{mM}$, respectively (Fig. 1a and b). We also observed that three proteins associated with cell cycle progression, cyclin D1 (G1 phase), cyclin B1 (G2 phase) and H3P (M phase), were dose-dependently suppressed by metformin (Fig. 1c). The cell cycle profiles in both cell lines showed that the subG1 population was dose-dependently increased by metformin while the G1 population was reduced (Fig. 1d). Thus cell cycle progression appears to be suppressed by metformin.

\section{Metformin induces apoptosis in HeLa cells}

Using FITC labeled Annexin V with PI in HeLa cells, we verified that metformin increases the incidence of apoptosis at both the early and late stages and necrosis (Fig. 2a and b). NAC failed to rescue the late apoptosis and necrosis, whereas it increased the percentage of early apoptosis. 

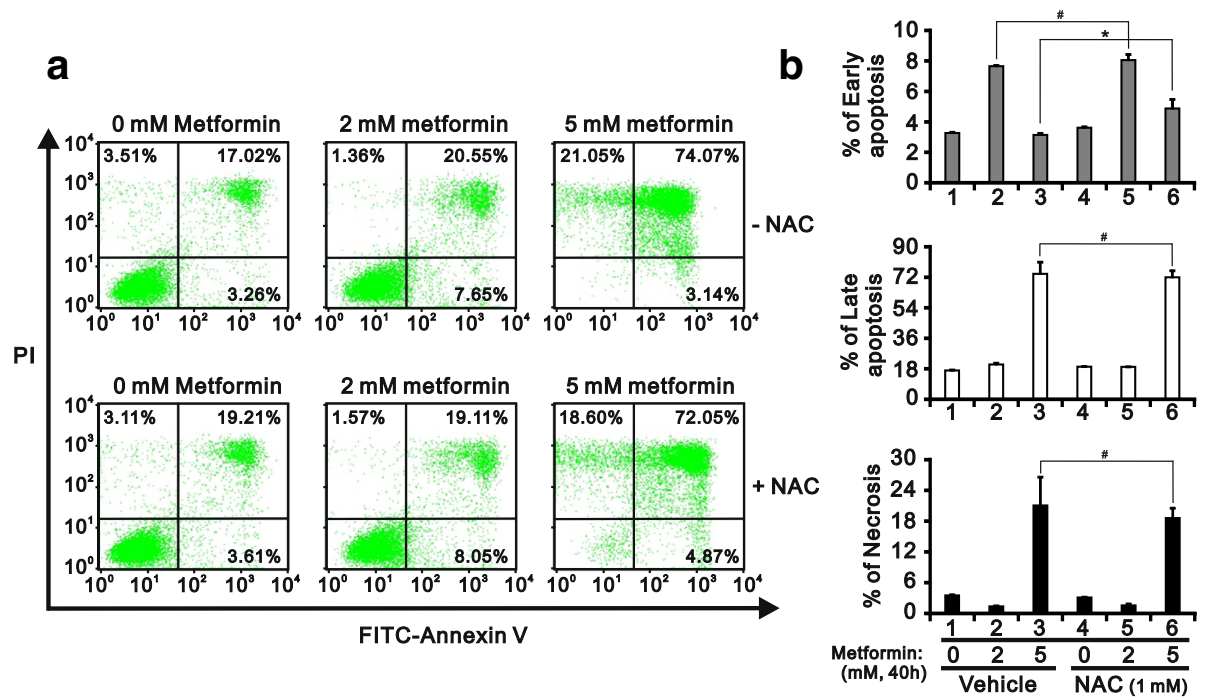

C

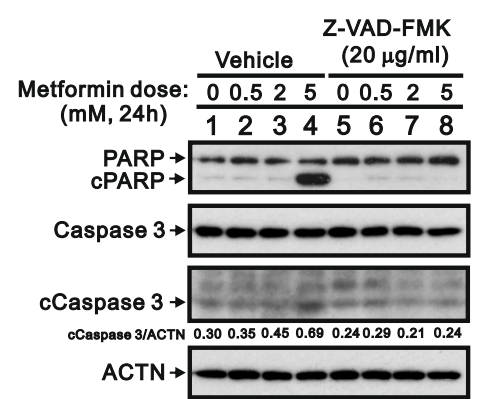

d

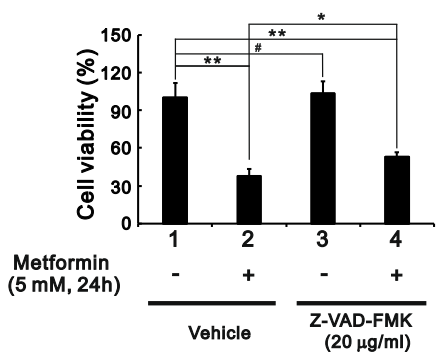

Fig. 2 Metformin-induced apoptosis in HeLa cells. a HeLa cells ( $8 \times 10^{4}$ cells) were incubated with the indicated concentration of metformin for $40 \mathrm{~h}$, after which cell death, apoptosis or necrosis were quantified using FITC-Annexin V and PI and flow cytometry. $\mathbf{b}$ Quantitative analysis of percentage of indicated stages is presented as the mean \pm S.D. of at least three independent experiments; \# $p>0.05$ and * $p<0.05$ (Student's t-test). c HeLa cells were incubated with the indicated concentration of metformin and $20 \mu \mathrm{g} / \mathrm{ml}$ Z-VAD-FMK for $24 \mathrm{~h}$. Cell lysates were then subjected to western blotting with antibodies against PARP and caspase 3. ACTN was the loading control. The protein levels of cleaved Caspase 3 (cCaspase 3) after normalization with the loading control protein ACTN are presented as fold change. $\mathbf{d}$ HeLa cells $\left(5 \times 10^{4}\right.$ cells) were treated with vehicle (DMSO), $5 \mathrm{mM}$ metformin, $20 \mu \mathrm{g} / \mathrm{ml}$ Z-VAD-FMK, or $5 \mathrm{mM}$ metformin plus $20 \mu \mathrm{g} / \mathrm{ml}$ Z-VAD-FMK for $24 \mathrm{~h}$. Quantitative analysis of cell viability is presented as the mean \pm S.D. of at least three independent experiments; $\# p>0.05,{ }^{*} p<0.05$, and ${ }^{* *} p<0.01$ (Student's t-test)

Consistent with that finding, western blot analysis of lysates from metformin-treated HeLa cell lysates revealed that levels of cPARP were increased in the metformin-treated cells (Fig. 2c). In addition, using the general caspase inhibitor Z-VAD-FMK, we found that metformin induced cleavage of PARP and caspase 3 and that approximately $40 \%$ of metformin-induced cell death was significantly rescued by Z-VAD-FMK (Fig. 2c and d). Taken together, these results suggest apoptosis may be a main cause of the cell death induced by metformin.

\section{Metformin promotes cytotoxic ROS generation unrelated to apoptosis}

We also used flow cytometry with DCFH-DA to examine the effect of metformin on intracellular ROS levels in HeLa cells. The results summarized in Fig. 3a show that with increases in the metformin concentration, ROS levels were obviously elevated relative the increases elicited by $\mathrm{H}_{2} \mathrm{O}_{2}$, which served as a positive control. Although ROS reportedly promote apoptosis [24], we discovered that the antioxidant NAC failed to prevent cPARP cleavage (Fig. 3b), but nevertheless partially suppressed metformin-induced cell death (Fig. 3c). Figs. 2 and 3 suggests ROS may contribute to metformin-induced cytotoxicity, though not via an apoptosis pathway.

Alternatively, cellular ROS production could lead to disruption of mitochondrial respiration and/or collapse of the mitochondrial membrane potential [25, 26]. Metformin not only lowers blood glucose but also suppresses complex-I in the electric transport 


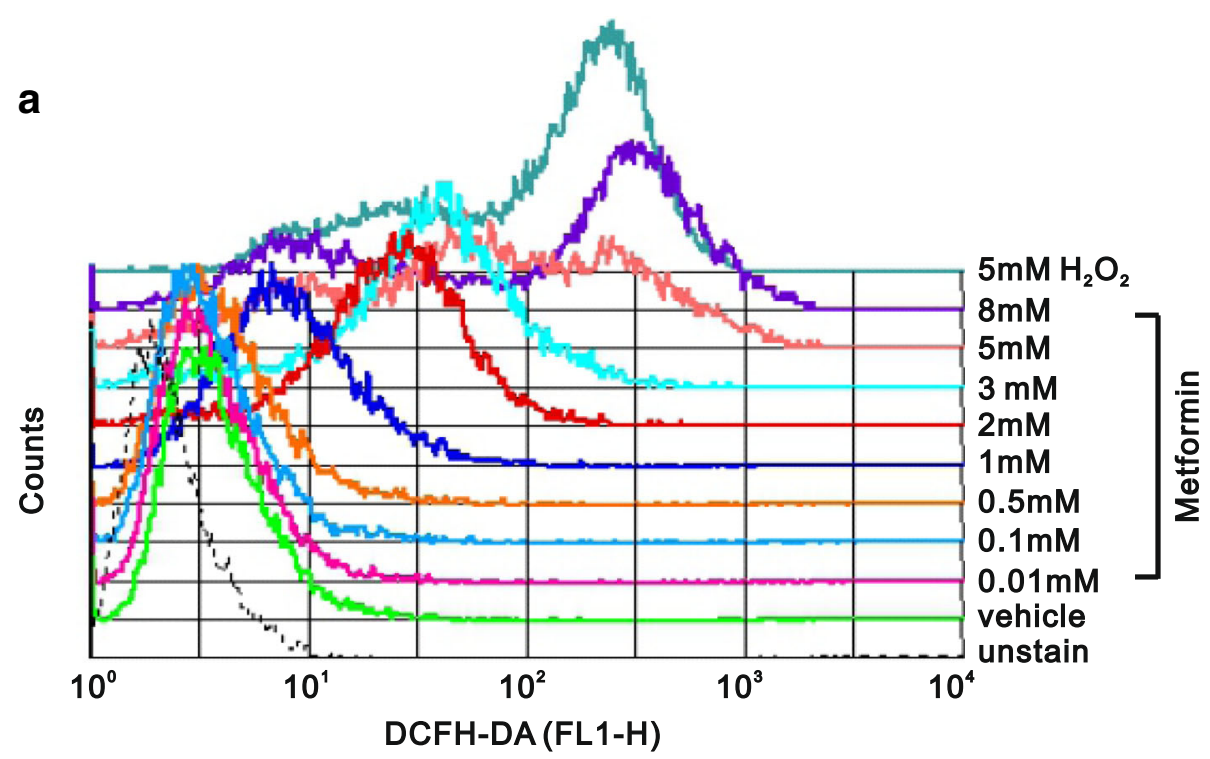

b

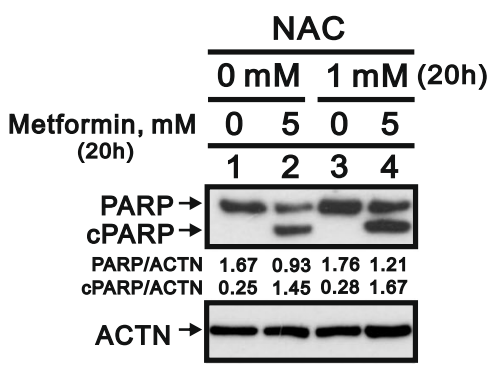

C

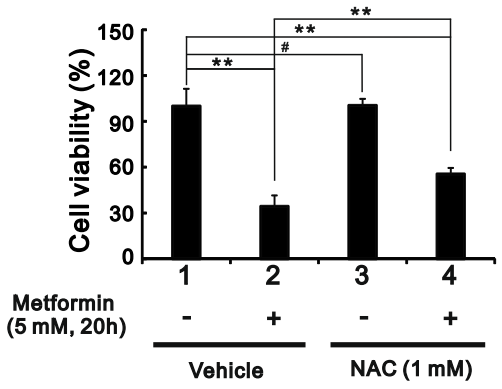

Fig. 3 Induction of ROS generation by metformin in HeLa cells. a HeLa cells were incubated for $20 \mathrm{~h}$ with various concentrations of metformin, after which the live cells was stained with $10 \mu \mathrm{M}$ DCFH-DA for $40 \mathrm{~min}$ at $37^{\circ} \mathrm{C}$ and assayed using a flow cytometer. b HeLa cells were incubated for $20 \mathrm{~h}$ with $5 \mathrm{mM}$ metformin and/or $1 \mathrm{mM}$ NAC. The cell lysates were then subjected to western blotting with an antibody against PARP. ACTN was the loading control. The protein levels of PARP and cleaved PARP (CPARP) after normalization with the loading control protein ACTN are presented as fold change. $\mathbf{c}$ HeLa cells $\left(5 \times 10^{4}\right.$ cells) were incubated for $20 \mathrm{~h}$ with vehicle (DMSO), $5 \mathrm{mM}$ metformin, $1 \mathrm{mM} \mathrm{NAC}$, or $5 \mathrm{mM}$ metformin plus $1 \mathrm{mM}$ NAC. Quantitative analysis of cell viability is presented as the mean \pm S.D. of at least three independent experiments; \# $p>0.05,{ }^{*} p<0.05$, and ${ }^{* *} p<0.01$ (Student's t-test)

chain $[27,28]$. For that reason, we measured the OCR and found that metformin decreased basal respiration, maximal respiratory capacity, and ATP-linked respiration in HeLa cells (Fig. 4a). To further examine the effect of metformin on mitochondrial membrane integrity, we used JC-1 staining to monitor the mitochondrial membrane potential. The results showed the metformin elicited increases in FL1-H (JC-1 monomers) and decreases in FL2-H (JC-1 aggregates) (Fig. $4 \mathrm{~b}$ and $\mathrm{c}$ ), which is indicative of depolarization of the mitochondrial membrane. This suggests metformin-induced ROS production in HeLa cells may reflect disruption of mitochondrial function.

\section{The functional role of DEC1 in metformin-induced} apoptosis

There is a link between the transcription factor DEC1 and apoptosis [29]. We observed that metformin reduced DEC1 levels and increased expression of cPARP proteins (Figs. 5a and 2b), which prompted us to evaluate DEC1's involvement in metformin-induced apoptosis. We initially determined the localization of DEC1 by separately examining the cytoplasmic, membrane, and nuclear fractions of HeLa cells. HSP90 $\alpha / \beta$, EGFR and PARP served as markers of cytoplasm, cell membrane and nuclei, respectively. We found that DEC1 was present mainly in the nucleus, and that MG132, a proteasome inhibitor, had little or no effect of DEC1 levels. 


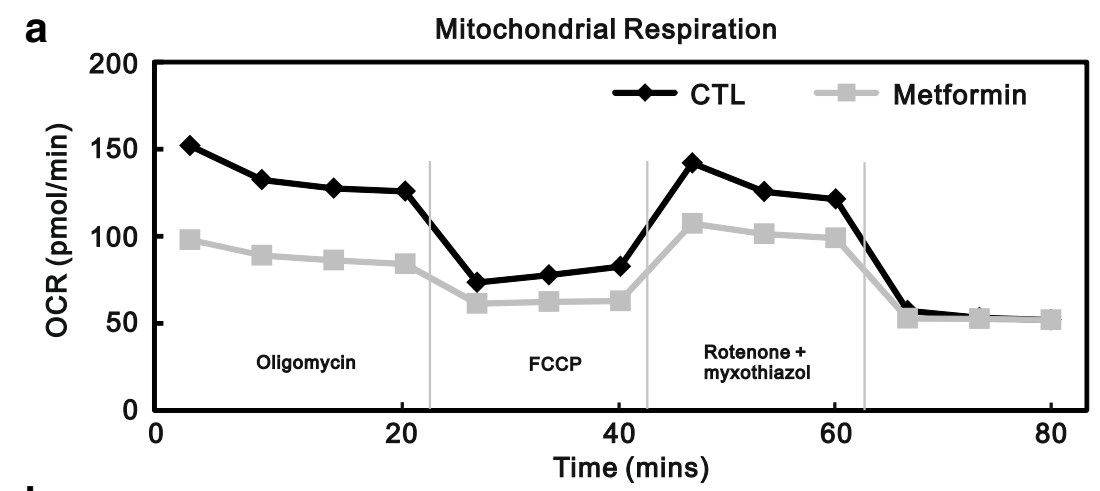

b
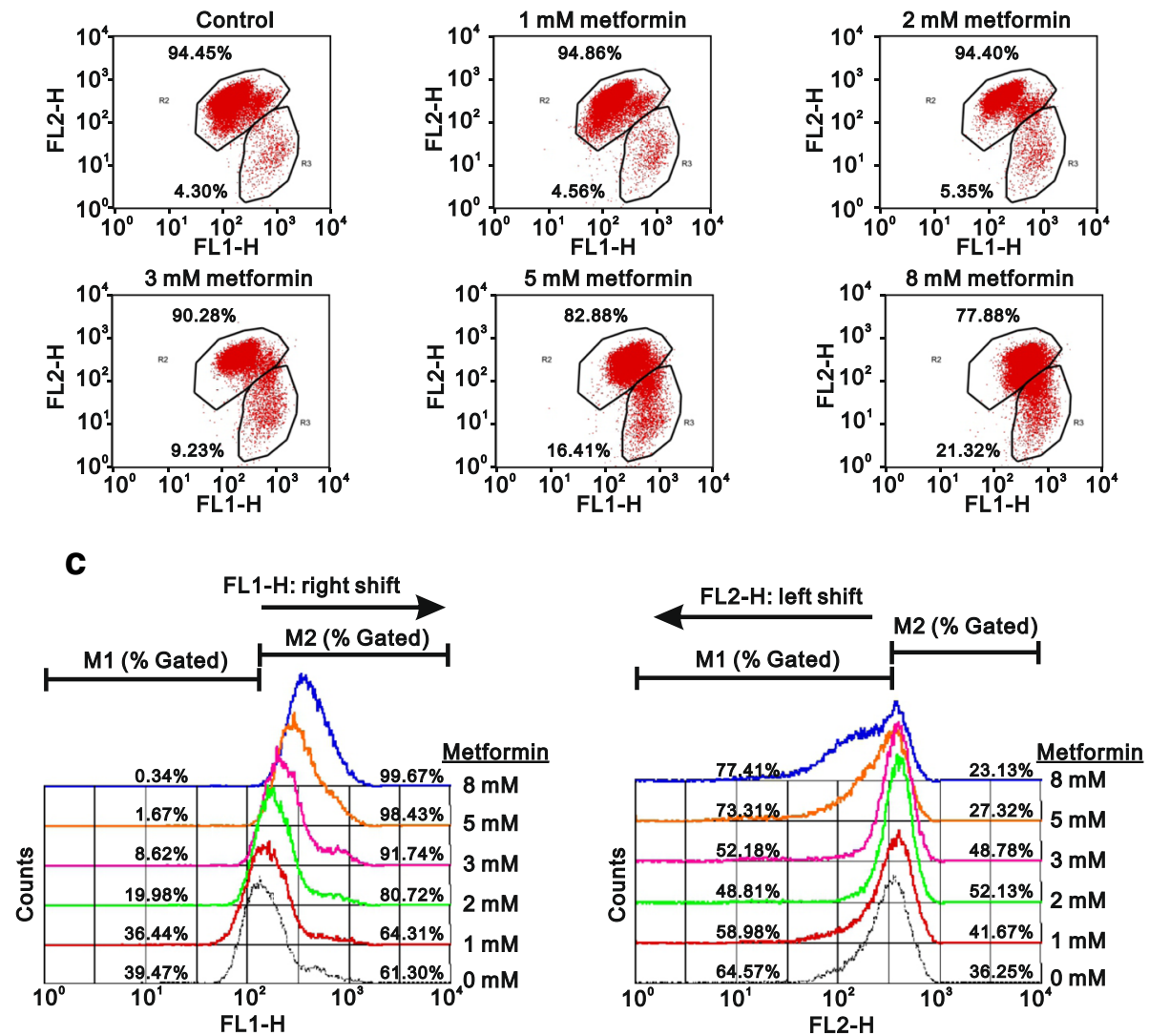

Fig. 4 Effect of metformin on mitochondrial function in HeLa cells. a HeLa cells were incubated for $20 \mathrm{~h}$ with $5 \mathrm{mM}$ metformin, after which the cellular OCR was measured in XF24 bioenergetic assays. b HeLa cells were incubated for $16 \mathrm{~h}$ with the indicated concentrations of metformin, after which JC-1 staining was analyzed using flow cytometry. c Changes in FL1-H and FL2-H were further evaluated using a FACS Calibur flow cytometer. The results are representative of two independent experiments

By contrast, metformin induced DEC1 degradation in all three fractions (Fig. 5b). Ectopic overexpression of pEGFP-DEC1 in HeLa cells confirmed that DEC1 localized primarily in the nucleus (Fig. 5c). To determine the relationship between DEC1 and apoptosis, HeLa cells were treated with metformin alone or in combination with ectopic DEC1 expression. Subsequent western blot analysis showed that ectopic DEC1 expression partially suppressed metformin-i nduced apoptosis (Fig. 5d), suggesting metformin may trigger apoptosis through downregulation of DEC1 expression.

\section{Involvement of p53 in metformin-induced apoptosis}

Early studies indicate $D E C 1$ gene is a target gene of p53 [30]. We found that metformin dose-dependently decreased levels of both p53 and DEC1 while making cells apoptotic. Overexpression of p53 partially rescued DEC1 levels and decreased the extent of apoptosis (Fig. 6a). These results suggest metformin may induce apoptosis 


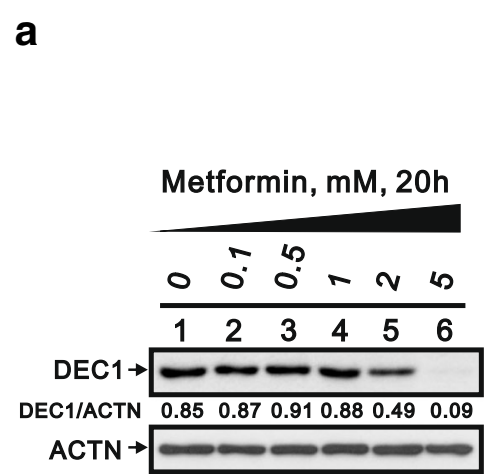

C
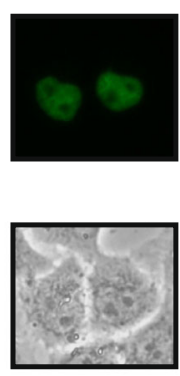

b

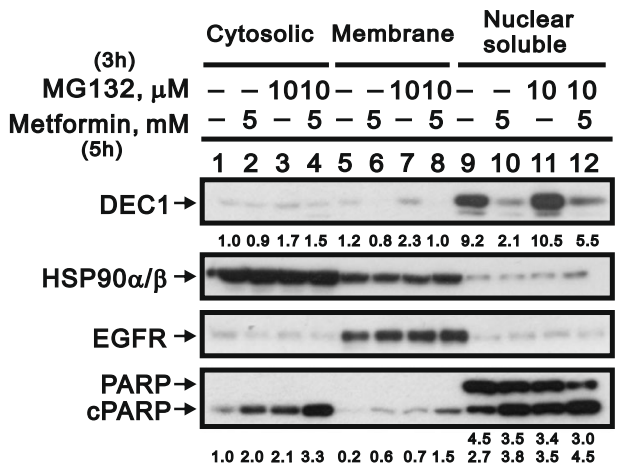

d

pEGFP.C2

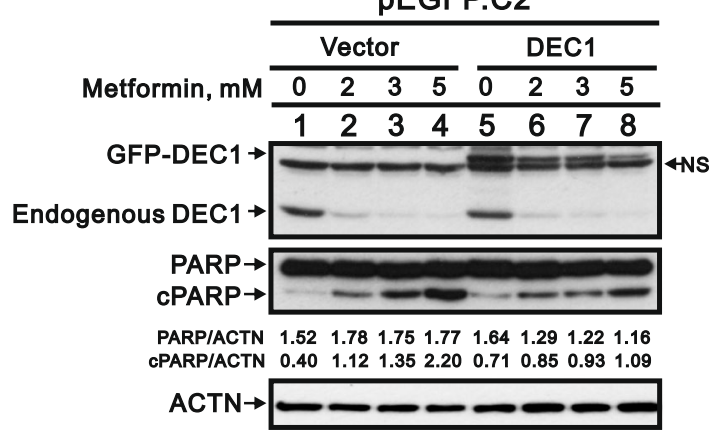

Fig. 5 Function of DEC1 in metformin-induced apoptosis in HeLa cells. a HeLa cells were incubated for $20 \mathrm{~h}$ with the indicated concentrations of metformin, after which the cell lysates were subjected to western blotting with an antibody against DEC1. ACTN was the loading control. The protein levels of DEC1 after normalization with the loading control protein ACTN are presented as fold change. $\mathbf{b}$ HeLa cells were incubated with $5 \mathrm{mM}$ metformin with and without $10 \mu \mathrm{M}$ MG132 for the indicated times. They were then lysed; divided into cytoplasmic, membrane, and nuclear fractions; and subjected to western blotting with antibodies against DEC1, HSP90a/ $\beta$ (cytoplasmic fraction), EGFR (membrane fraction) and PARP (intact: nuclear fraction; cleaved: nuclear and cytoplasmic fractions). The protein levels of cleaved DEC1, PARP, and CPARP are presented as fold change. c HeLa cells were transiently transfected with $2 \mu \mathrm{g}$ pEGFP.DEC1 for $5 \mathrm{~h}$ and then were observed with fluorescence-microscopy. d HeLa cells were transiently transfected with $2 \mu \mathrm{g}$ of pEGFP vector and pEGFP.DEC1 and incubated for $13 \mathrm{~h}$ with $5 \mathrm{mM}$ metformin. The cell lysates were subjected to western blotting with antibodies against DEC1 and PARP. ACTN was the loading control. The protein levels of PARP and cleaved PARP (CPARP) after normalization with the loading control protein ACTN are presented as fold change. The results are representative of three independent experiments

in HeLa cells by acting on p53 upstream of DEC1. To better understand the mechanism underlying the downregulation of p53 by metformin, we first used MG132 to determine whether metformin induces degradation of $\mathrm{p} 53$ via a proteasome-dependent pathway. We observed that p53 degradation was mediated through the proteasomes, but MG132 failed to fully suppress p53 degradation elicited by metformin (Fig. 6b). Subsequent application of RNA and protein synthesis inhibitors (actinomycin D and cycloheximide, respectively) revealed no effect of metformin on p53 expression (Fig. 6c, compare lanes 1-4). Moreover, actinomycin D appeared to increased p53 levels and to exert a protective effect against metformin-induced p53 degradation (Fig. 6d, compare lanes 5-8).

Treatment with cycloheximide for $12 \mathrm{~h}$ elicited no further effect on p53 levels, most likely because p53 has a short half-life in HeLa cells (Fig. 6d, compare lanes 912) [31]. To overcome the time-window limitation for cycloheximide treatment, we re-examined the timing of metformin treatment and the stability of endogenous p53. Metformin-induced p53 degradation was first detected after around $2 \mathrm{~h}$ of treatment (Fig. 6e), but it was difficult to detect p53 in HeLa cells after only $10 \mathrm{~min}$ of cycloheximide treatment $(50 \mu \mathrm{g} / \mathrm{ml})$ (Fig. 6f), which is consistent with our earlier study [31]. We therefore decreased the cycloheximide concentration from $50 \mu \mathrm{g} / \mathrm{ml}$ to $50 \mathrm{ng} / \mathrm{ml}$ and increased the concentration of metformin from 5 to $10 \mathrm{mM}$. Under those conditions, metformin accelerated the degradation of p53 in the presence of cycloheximide. It thus appears that metformin reduces p53 levels in HeLa cells by reducing the protein's stability (Fig. 6g). 


\section{a}

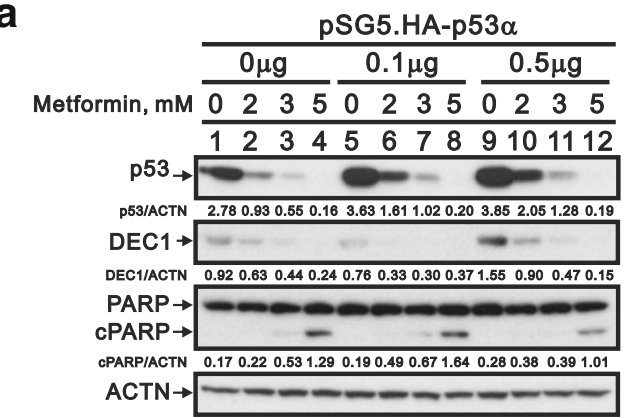

C

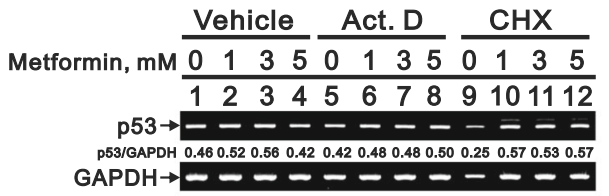

d

\begin{tabular}{|c|c|c|c|}
\hline \multirow{3}{*}{ Metformin, mM } & Vehicle & \multicolumn{2}{|c|}{ Act. D $\quad \mathrm{CHX}$} \\
\hline & $\begin{array}{llll}0 & 1 & 3 & 5 \\
\end{array}$ & $\begin{array}{llll}0 & 1 & 3 & 5 \\
\end{array}$ & $\begin{array}{llll}0 & 1 & 3 & 5 \\
\end{array}$ \\
\hline & 12234 & $\begin{array}{llll}5 & 6 & 7 & 8\end{array}$ & 9101112 \\
\hline 8 & $-1-1$ & E & \\
\hline 3/ACTN 2 & $\begin{array}{lll}2.4 & 2.51 .8 \\
-- & -\end{array}$ & 3.4 & \\
\hline
\end{tabular}

b

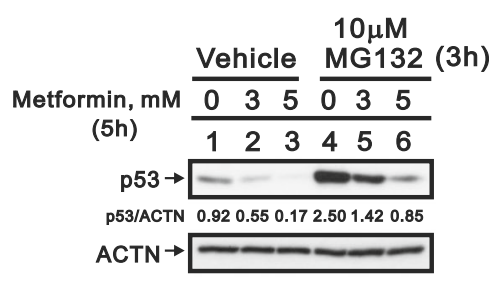

e

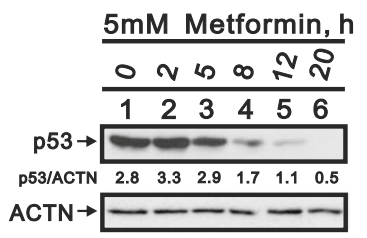

f

g

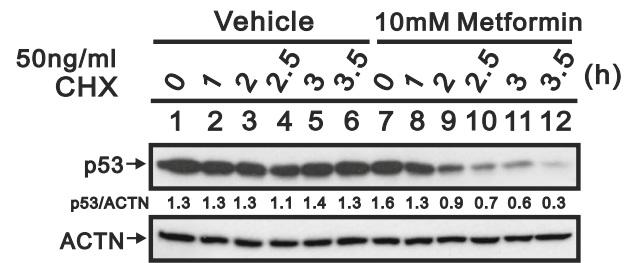

Fig. 6 Transcriptional and translational regulation of p53 in HeLa cells. a HeLa cells were transiently transfected with $0.5 \mu \mathrm{g}$ of pSG5.HA vector or the indicated amount of pSG5.HA.p53 and incubated for $12 \mathrm{~h}$ with $5 \mathrm{mM}$ metformin. The cell lysates were subjected to western blotting with antibodies against p53, DEC1, and PARP. ACTN was the loading control. The protein levels of p53, DEC1, and CPARP after normalization with the loading control protein ACTN are presented as fold change. $\mathbf{b}$ HeLa cells were incubated for $5 \mathrm{~h}$ with the indicated concentrations of metformin with or without $10 \mu \mathrm{M}$ MG132, after which the cell lysates were subjected to western blotting with an antibody against p53. ACTN was the loading control. The protein levels of p53 after normalization with the loading control protein ACTN are presented as fold change. $\mathbf{c}$ and $\mathbf{d}$ HeLa cells were incubated for $12 \mathrm{~h}$ with the indicated concentrations of metformin with and without $0.1 \mu \mathrm{M}$ actinomycin $\mathrm{D}$ (Act $\mathrm{D}$ ) or $50 \mu \mathrm{g} / \mathrm{ml}$ cycloheximide (CHX). Levels of p53 mRNA and protein were then assayed in the cell lysates using RT-PCR (c) and western blotting (d), respectively. GAPDH mRNA was the mRNA loading control; ACTN was the protein loading control. e and $\mathbf{f}$ HeLa cells were incubated with 5 mM metformin (e) or $50 \mathrm{\mu g} / \mathrm{ml} \mathrm{CHX} \mathrm{(f)} \mathrm{for} \mathrm{the} \mathrm{indicated} \mathrm{times,} \mathrm{after} \mathrm{which} \mathrm{cell} \mathrm{lysates} \mathrm{were} \mathrm{subjected} \mathrm{to} \mathrm{western} \mathrm{blotting} \mathrm{with} \mathrm{an} \mathrm{antibody} \mathrm{against}$ p53. $\mathbf{g}$ HeLa cells were incubated for the indicated times with $10 \mathrm{mM}$ metformin with and without $50 \mathrm{ng} / \mathrm{ml} \mathrm{CHX}$. The cell lysates were then subjected to western blotting with an antibody against p53. $\mathbf{d}-\mathbf{g}$ The protein levels of p53 after normalization with the loading control protein ACTN are presented as fold change. The results are representative of three independent experiments

\section{Loss-of-function of p53 and DEC1 for metformin-induced apoptosis}

To further verify the contribution of p53 and DEC 1 to metformin-induced apoptosis, we applied a small-molecule inhibitor of $\mathrm{p} 53$, pifithrin- $\alpha$, which reportedly inhibits several p53-dependent processes in vitro, including UV-induced expression of cyclin G, p21, and MDM-2
[32]. We also assessed the effect of DEC1 knockdown using a short-hairpin silencing system (Fig. 7). Our results showed that, by itself, pifithrin- $\alpha$ had no apparent effect on PARP cleavage. When combined $10 \mathrm{mM}$ metformin, however, it dramatically increased levels of cPARP and caspase 3 (Fig. 7a). Knocking down DEC1 also increased levels of cPARP (Fig. 7b, compare lanes 9 with 7). In 


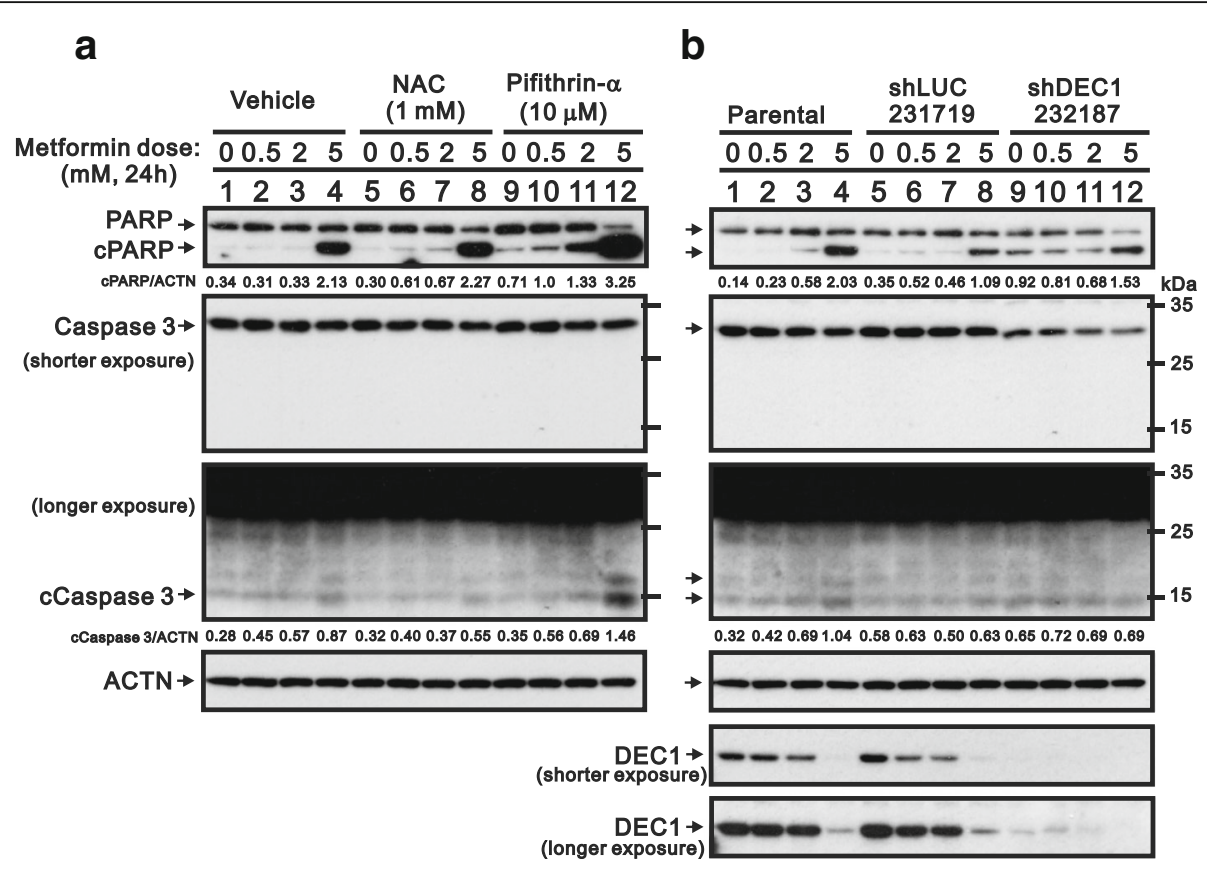

Fig. 7 Verification of p53 and DEC1 into the metformin-induced apoptosis in HeLa cells. a HeLa cells were incubated for $24 \mathrm{~h}$ with the indicated concentrations of metformin, $1 \mathrm{mM} \mathrm{NAC}$, and $10 \mu \mathrm{M}$ pifithrin-a. The cell lysates were then subjected to western blotting with antibodies against PARP and caspase 3. ACTN was the loading control. b Following DEC1 knockdown in HeLa cells, the cells were incubated for $24 \mathrm{~h}$ with the indicated concentration of metformin. The cell lysates were then subjected to western blotting with antibodies against PARP and Caspase 3. ACTN was the loading control and DEC1 was the silencing efficiency of shDEC1. The protein levels of CPARP and cCaspase 3 after normalization with the loading control protein ACTN are presented as fold change. The results are representative of three independent experiments

contrast to previously reported effects [33, 34], we observed that pifithrin- $\alpha$ induced apoptosis in HeLa cells, which is consistent with its promotion of p53-mediated apoptosis in JB6 cells [35].

\section{Discussion}

Among the three biguanides (buformin, metformin. and phenformin) developed for the treatment of diabetes, increased cardiac mortality and risk of lactic acidosis led to withdrawal of buformin and phenformin in the early 1970 s [2]. On the other hand, the lower risk and beneficial characteristics of metformin has enabled it to become one of the most popular medications in the world. Moreover, higher doses of biguanides may have direct antitumor effects [36]. Our findings suggest the antitumor effects of high-dose metformin are mediated through multiple pathways involving apoptosis, ROS generation, and downregulation of p53-related proteins. We propose that metformin may directly decrease p53 abundance in sensitive cells, which in turn leads to downregulation of p53 target genes (e.g., DEC1) and to induction of apoptosis. Metformin also induces ROS generation by suppressing the mitochondrial respiration rate and membrane potential. All of the abovementioned effects contribute to metformin-induced cell death (Fig. 8), and several clinical trials have shown promising results with metformin against various cancers, including breast cancer, gastric cancer, and pancreatic ductal adenocarcinoma, among others [37-39]. It is therefore crucial to further realize the molecular mechanisms of biguanides, which have the potential to contribute to the development in therapies for not only diabetes but also cancer.

Autophagy and apoptosis are two major cell death pathways [40]. One study showed that suppressing autophagy using chloroquine enhanced palmitic acid-induced apoptosis while increasing ROS generation [41]. However, our findings showed that NAC, a well-known ROS scavenger failed to inhibit the metformin-induced apoptosis and the cleavage of PARP. These results suggest that in our study apoptosis may be induced through suppression of autophagy, not through ROS generation. The precise relationship between autophagy and apoptosis remains to be further elucidated in HeLa cells. Several studies have demonstrated that metformin decreases ROS production through reduction of NAD (P) $\mathrm{H}$ oxidase activity [42, 43]. In addition to the inhibition of NAD (P) H oxidase activity, metformin may increase the ROS generation through other mechanisms in various cell types [44-46]. One study showed that there is complex interplay among processes regulating ROS, autophagy and apoptosis in response to expression of p53-inducible glycolysis and apoptosis regulator (TIGAR), which functions as a fructose 


\section{Metformin}

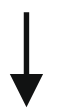

Mitochondrial dysfunction

\section{Respiration $\downarrow$

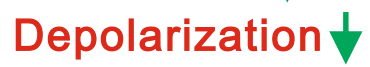

100

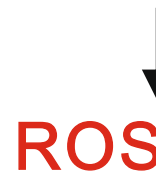

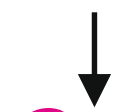
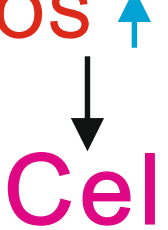

.
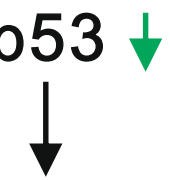

DEC $1 \downarrow$

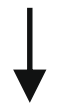

Apoptosis 4

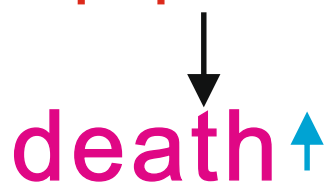

Fig. 8 Proposed working mechanisms of metformin in cancer cells. Metformin may directly decrease p53 in sensitive cells, which would in turn downregulate expression of its target gene, DEC1, leading to apoptosis. Metformin not only induces cellular apoptosis but also induces ROS generation through repression of mitochondrial respiration and membrane potential to kill cancer cells. Thus, apoptosis, mitochondrial dysfunction, and ROS generation all contribute to the induction of HeLa cell death by metformin

2,6-bisphosphatase [15]. TIGAR promotes activity in the pentose phosphate pathway and helps lower intracellular ROS. In the present study, metformin-mediated reduction in endogenous p53 may have led to ROS generation via downregulation of TIGAR expression.

The transcription factor p53 is a known tumor suppressor and is stabilized and activated for cellular responses to a variety of stresses, including hypoxia, DNA damage, and oncogene expression. These cellular responses include cell cycle arrest, apoptosis, senescence, and so on $[13,14]$. It is commonplace for p53 activity and the activities of other tumor suppressors to be inhibited within tumors so as to inactivate cell-death pathways. Because HeLa cells are infected by human papillomavirus (HPV), they are able to express oncoprotein E6 to maintain endogenous wild-type p53 at low levels for human cervical tumorigenesis [22, 47]. Our findings in the present study suggest that as described in our earlier DXR work [48], metformin modulates levels of endogenous p53 to trigger various cellular activities altering expression of p53 target genes, including p21 (cell cycle inhibitor) [49], Bax (apoptosis inducer) [50], DNA damage regulated autophagy modulator 1 (autophagy inducer) [51], DEC1 (senescence inducer) [30], and survivin (apoptosis inhibitor) [52]. Given that p53 is an apoptosis inducer, the loss of survivin's anti-apoptosis effect may explain why metformin, alone or in combination with pifithrin- $\alpha$, induces apoptosis despite the reduction in p53 $[52,53]$. However, further experiments will be needed to determine the contributions made by p53 and its target genes to the various dose-dependent effects of metformin. Several studies have shown that metformin may increase or decrease endogenous p53 via mechanisms involving miR-34a, USP7, and mitophagy $[20,21,54]$. Additional experiments will be required to clarify how metformin selectively mediates increases or decreases in the levels of p53.

It was recently reported that metformin reduces the risk of cervical cancer [55]. Although the mechanisms underlying the reduced risk remain to be explored, the authors of that study suggest the reduction in risk reflects metformin's ability to reduce inflammation via inhibition of nuclear factor $\mathrm{kB}$ and STAT3 pathways. Taken together, that work and our present findings suggest metformin has the potential to suppress the proliferation and growth of cervical cancer cells and may be a useful addition to the currently used methods for the prevention and treatment of cervical cancer.

\section{Conclusions}

In the present study, we demonstrated that metformin has several actions that suppress cell survival, including induction of apoptosis and ROS generation. The regulatory mechanisms of metformin may reflect its ability to reduce the stability, and thus the abundance, of endogenous wild-type p53. This would be expected to alter expression of many p53-dependent target genes responsible for various cell death pathways. Our work fully supports the reposition of metformin for cancer treatment or combination therapy with currently used cancer therapeutic agents.

\section{Abbreviations}

Act D: Actinomycin D; ACTN: a-actinin; AMPK: AMP-activated protein kinase; CEB: cytoplasmic extraction buffer; CHX: cycloheximide; CPARP: cleaved polyADP-ribose polymerase; DCFH-DA: 2',7-dichlorofluorescein diacetate;

DEC1: Differentiated Embryo Chondrocyte 1; DMEM: Dulbecco's modified Eagle's medium; EMT: epithelial-to-mesenchymal transition;

FACS: fluorescence- activated cell sorting; FBS: fetal bovine serum; FCCP: carbonyl cyanide 4-[trifluoromethoxy] phenylhydrazone; FITC: fluorescein isothiocyanate; $\mathrm{H}_{2} \mathrm{O}_{2}$ : hydrogen peroxide; $\mathrm{H} 3 \mathrm{P}$ : phosphorylation at Ser 10 Histone H3; JC-1: 5, 5',6,6'-tetrachloro-1,1',3,3'-tetraethylbenzimidazolylcarbocyanine iodide; MEB: membrane extraction buffer; miRs: microRNAs; MTT: thiazolyl blue tetrazlium bromide; NAC: N-acetyl cysteine; NEB: nuclear extraction buffer; OCR: oxygen consumption rate; OCT1: organic cation transporter-1; HPV: human papillomavirus; PBS: phosphate buffered saline; PI: propidium iodide; ROS: reactive oxygen species; RPMI: Roswell Park Memorial Institute; RT-PCR: reverse transcription-polymerase chain reaction; TIGAR: TP53-inducible glycolysis and apoptosis regulator

\section{Acknowledgements}

We gratefully acknowledge all of the funding sources.

\section{Funding}

This work was supported by grants from the Ministry of National DefenseMedical Affairs Bureau [MAB-106-20 to S-M HUANG], the Ministry of Science 
and Technology [MOST 105-2314-B-016-047 to C-L HO], and Teh-Tzer Study Group for Human Medical Research Foundation [A106-1017 to C-L HO], Taiwan, ROC.

\section{Availability of data and materials}

All supporting data have been shown in current manuscript.

\section{Authors' contributions}

SMHL conceived and, analyzed data and wrote the paper. STL and YLC carried out experiments and analyzed data. CLH and SMH conceived of the study, and participated in its design and coordination and helped to draft the manuscript. All authors read and approved the final manuscript.

\section{Ethics approval and consent to participate}

"Not applicable" (The present paper did not involve the use of any animal or human data).

\section{Consent for publication}

"Not applicable".

\section{Competing interests}

The authors declare that they have no competing interests.

\section{Publisher's Note}

Springer Nature remains neutral with regard to jurisdictional claims in published maps and institutional affiliations.

Received: 7 June 2018 Accepted: 18 October 2018 Published online: 15 November 2018

\section{References}

1. American Diabetes Association. Standards of medical care in diabetes--2014. Diabetes Care. 2014;37(Suppl 1):S14-80.

2. Foretz M, Guigas B, Bertrand L, Pollak M, Viollet B. Metformin: from mechanisms of action to therapies. Cell Metab. 2014;20:953-66.

3. Gong L, Goswami S, Giacomini KM, Altman RB, Klein TE. Metformin pathways: pharmacokinetics and pharmacodynamics. Pharmacogenet Genomics. 2012;22:820-7.

4. Viollet B, Guigas B, Sanz Garcia N, Leclerc J, Foretz M, Andreelli F. Cellular and molecular mechanisms of metformin: an overview. Clin Sci (Lond) 2012;122:253-70.

5. Novelle MG, Ali A, Dieguez C, Bernier M, de Cabo R. Metformin. A Hopeful Promise in Aging Research. CSH Perspect Med. 2016;6:a025932.

6. Scheen AJ, Esser N, Paquot N. Antidiabetic agents. Potential anti-inflammatory activity beyond glucose control. Diabetes Metab. 2015;41:183-94.

7. Kasznicki J, Sliwinska A, Drzewoski J. Metformin in cancer prevention and therapy. Ann Transl Med. 2014:2:57.

8. Rizos CV, Elisaf MS. Metformin and cancer. Eur J Pharmacol. 2013;705:96-108.

9. Del Barco S, Vazquez-Martin A, Cufi S, Oliveras-Ferraros C, Bosch-Barrera J, Joven J, Martin-Castillo B, Menendez JA. Metformin: multi-faceted protection against cancer. Oncotarget. 2011;2:896-917.

10. Jalving M, Gietema JA, Lefrandt JD, de Jong S, Reyners AK, Gans RO, de Vries EG. Metformin: taking away the candy for cancer? Eur J Cancer. 2010; 46:2369-80.

11. Bao B, Azmi AS, Ali S, Zaiem F, Sarkar FH. Metformin may function as anticancer agent via targeting cancer stem cells: the potential biological significance of tumor-associated miRNAs in breast and pancreatic cancers. Ann Transl Med. 2014:2:59.

12. Barriere G, Tartary M, Rigaud M. Metformin: a rising star to fight the epithelial mesenchymal transition in oncology. Anti Cancer Agents Med Chem. 2013;13:333-40.

13. Bieging KT, Mello SS, Attardi LD. Unravelling mechanisms of p53-mediated tumour suppression. Nat Rev Cancer. 2014;14:359-70.

14. Oren M. Decision making by p53: life, death and cancer. Cell Death Differ. 2003:10:431-42

15. Bensaad K, Tsuruta A, Selak MA, Vidal MN, Nakano K, Bartrons R, Gottlieb E, Vousden $\mathrm{KH}$. TIGAR, a p53-inducible regulator of glycolysis and apoptosis. Cell. 2006;126:107-20.

16. Haupt S, Berger M, Goldberg Z, Haupt Y. Apoptosis - the p53 network. J Cell Sci. 2003;116:4077-85.
17. Schuler M, Green DR. Mechanisms of p53-dependent apoptosis. Biochem Soc Trans. 2001;29:684-8.

18. Polyak K, Xia Y, Zweier JL, Kinzler KW, Vogelstein B. A model for p53induced apoptosis. Nature. 1997:389:300-5.

19. Speidel D. Transcription-independent p53 apoptosis: an alternative route to death. Trends Cell Biol. 2010:20:14-24.

20. Song YM, Lee WK, Lee YH, Kang ES, Cha BS, Lee BW. Metformin restores Parkin-mediated Mitophagy, suppressed by cytosolic p53. Int J Mol Sci. 2016;17:122.

21. $\mathrm{Xu}$ Y, Lu S. Metformin inhibits esophagus cancer proliferation through upregulation of USP7. Cell Physiol Biochem. 2013;32:1178-86.

22. Huang SM, Schonthal AH, Stallcup MR. Enhancement of p53-dependent gene activation by the transcriptional coactivator Zac1. Oncogene. 2001;20: 2134-43.

23. Huang SM, Huang SP, Wang SL, Liu PY. Importin alpha1 is involved in the nuclear localization of Zac1 and the induction of p21WAF1/CIP1 by Zac1. Biochem J. 2007:402:359-66.

24. Mukhopadhyay S, Das DN, Panda PK, Sinha N, Naik PP, Bissoyi A, Pramanik K, Bhutia SK. Autophagy protein Ulk1 promotes mitochondrial apoptosis through reactive oxygen species. Free Radic Biol Med. 2015;89:311-21.

25. Starkov AA. The role of mitochondria in reactive oxygen species metabolism and signaling. Ann N Y Acad Sci. 2008;1147:37-52.

26. Venditti $P$, Di Stefano L, Di Meo S. Mitochondrial metabolism of reactive oxygen species. Mitochondrion. 2013;13:71-82.

27. Owen MR, Doran E, Halestrap AP. Evidence that metformin exerts its antidiabetic effects through inhibition of complex 1 of the mitochondrial respiratory chain. Biochem J. 2000;348:607-14.

28. Birsoy K, Possemato R, Lorbeer FK, Bayraktar EC, Thiru P, Yucel B, Wang T, Chen WW, Clish CB, Sabatini DM. Metabolic determinants of cancer cell sensitivity to glucose limitation and biguanides. Nature. 2014;508:108-12.

29. Li Y, Xie M, Yang J, Yang D, Deng R, Wan Y, Yan B. The expression of antiapoptotic protein survivin is transcriptionally upregulated by DEC1 primarily through multiple sp1 binding sites in the proximal promoter. Oncogene. 2006:25:3296-306.

30. Qian Y, Zhang J, Yan B, Chen X. DEC1, a basic helix-loop-helix transcription factor and a novel target gene of the p53 family, mediates p53-dependent premature senescence. J Biol Chem. 2008;283:2896-905.

31. Lu GY, Huang SM, Liu ST, Liu PY, Chou WY, Lin WS. Caffeine induces tumor cytotoxicity via the regulation of alternative splicing in subsets of cancerassociated genes. Int J Biochem Cell Biol. 2014:47:83-92.

32. Komarov PG, Komarova EA, Kondratov RV, Christov-Tselkov K, Coon JS, Chernov MV, Gudkov AV. A chemical inhibitor of p53 that protects mice from the side effects of cancer therapy. Science. 1999;285:1733-7.

33. Zhu X, Yu QS, Cutler RG, Culmsee CW, Holloway HW, Lahiri DK, Mattson MP, Greig NH. Novel p53 inactivators with neuroprotective action: syntheses and pharmacological evaluation of 2-imino-2,3,4,5,6,7-hexahydrobenzothiazole and 2-imino-2,3,4,5,6,7-hexahydrobenzoxazole derivatives. J Med Chem. 2002:45:5090-7.

34. Culmsee C, Zhu X, Yu QS, Chan SL, Camandola S, Guo Z, Greig NH, Mattson MP. A synthetic inhibitor of p53 protects neurons against death induced by ischemic and excitotoxic insults, and amyloid beta-peptide. J Neurochem. 2001;77:220-8.

35. Kaij A, Zhang Y, Nomura M, Bode AM, Ma WY, She OB, Dong Z. Pifithrin-alpha promotes p53-mediated apoptosis in JB6 cells. Mol Carcinog. 2003;37:138-48.

36. Menendez JA, Quirantes-Pine R, Rodriguez-Gallego E, Cufi S, Corominas-Faja B, Cuyas E, Bosch-Barrera J, Martin-Castillo B, Segura-Carretero A, Joven J. Oncobiguanides: Paracelsus' law and nonconventional routes for administering diabetobiguanides for cancer treatment. Oncotarget. 2014;5: 2344-8.

37. Sonnenblick A, Agbor-Tarh D, Bradbury I, Di Cosimo S, Azim HA Jr, Fumagalli D, Sarp S, Wolff AC, Andersson M, Kroep J, et al. Impact of diabetes, insulin, and metformin use on the outcome of patients with human epidermal growth factor receptor 2-positive primary breast Cancer: analysis from the ALTTO phase III randomized trial. J Clin Oncol. 2017;35:1421-9.

38. Lee CK, Jung M, Jung I, Heo SJ, Jeong YH, An JY, Kim HI, Cheong JH, Hyung WJ, Noh SH, et al. Cumulative metformin use and its impact on survival in gastric Cancer patients after gastrectomy. Ann Surg. 2016;263:96-102.

39. Amin S, Mhango G, Lin J, Aronson A, Wisnivesky J, Boffetta P, Lucas AL. Metformin improves survival in patients with pancreatic ductal adenocarcinoma and pre-existing diabetes: a propensity score analysis. Am J Gastroenterol. 2016;111:1350-7. 
40. Yonekawa T, Thorburn A. Autophagy and cell death. Essays Biochem. 2013; 55:105-17.

41. Jiang XS, Chen XM, Wan JM, Gui HB, Ruan XZ, Du XG. Autophagy protects against palmitic acid-induced apoptosis in podocytes in vitro. Sci Rep. 2017; 7:42764.

42. Kelly B, Tannahill GM, Murphy MP, O'Neill LA. Metformin inhibits the production of reactive oxygen species from NADH:ubiquinone oxidoreductase to limit induction of interleukin-1 beta (IL-1 beta) and boosts Interleukin-10 (IL-10) in lipopolysaccharide (LPS)-activated macrophages. J Biol Chem. 2015;290:20348-59.

43. Ouslimani N, Peynet J, Bonnefont-Rousselot D, Therond P, Legrand A, Beaudeux JL. Metformin decreases intracellular production of reactive oxygen species in aortic endothelial cells. Metabolism. 2005;54:829-34

44. Wang X, Li R, Zhao X, Yu X, Sun Q. Metformin promotes HaCaT cell apoptosis through generation of reactive oxygen species via Raf-1-ERK1/2Nrf2 inactivation. Inflammation. 2018;41:948-58.

45. Mogavero A, Maiorana MV, Zanutto S, Varinelli L, Bozzi F, Belfiore A, Volpi CC, Gloghini A, Pierotti MA, Gariboldi M. Metformin transiently inhibits colorectal cancer cell proliferation as a result of either AMPK activation or increased ROS production. Sci Rep. 2017;7:15992.

46. Veleba J, Kopecky J Jr, Janovska P, Kuda O, Horakova O, Malinska H, Kazdova L, Oliyarnyk O, Skop V, Trnovska J, et al. Combined intervention with pioglitazone and $n-3$ fatty acids in metformin-treated type 2 diabetic patients: improvement of lipid metabolism. Nutr Metab (Lond). 2015;12:52.

47. May P, May E. Twenty years of p53 research: structural and functional aspects of the p53 protein. Oncogene. 1999;18:7621-36.

48. Chang YL, Lee HJ, Liu ST, Lin YS, Chen TC, Hsieh TY, Huang HS, Huang SM. Different roles of $\mathrm{p} 53$ in the regulation of DNA damage caused by 1,2heteroannelated anthraquinones and doxorubicin. Int J Biochem Cell Biol. 2011:43:1720-8.

49. El-Deiry WS, Tokino T, Velculescu VE, Levy DB, Parsons R, Trent JM, Lin D, Mercer WE, Kinzler KW, Vogelstein B. WAF1, a potential mediator of p53 tumor suppression. Cell. 1993;75:817-25.

50. Chipuk JE, Kuwana T, Bouchier-Hayes L, Droin NM, Newmeyer DD, Schuler M, Green DR. Direct activation of Bax by p53 mediates mitochondrial membrane permeabilization and apoptosis. Science. 2004;303:1010-4.

51. Crighton D, Wilkinson S, O'Prey J, Syed N, Smith P, Harrison PR, Gasco M, Garrone O, Crook T, Ryan KM. DRAM, a p53-induced modulator of autophagy, is critical for apoptosis. Cell. 2006;126:121-34.

52. Mirza A, McGuirk M, Hockenberry TN, Wu Q, Ashar H, Black S, Wen SF, Wang $L$, Kirschmeier P, Bishop WR, et al. Human survivin is negatively regulated by wild-type p53 and participates in p53-dependent apoptotic pathway. Oncogene. 2002;21:2613-22.

53. Altieri DC. Survivin, versatile modulation of cell division and apoptosis in cancer. Oncogene. 2003;22:8581-9.

54. Do MT, Kim HG, Choi JH, Jeong HG. Metformin induces microRNA-34a to downregulate the Sirt1/Pgc-1alpha/Nrf2 pathway, leading to increased susceptibility of wild-type p53 cancer cells to oxidative stress and therapeutic agents. Free Radic Biol Med. 2014;74:21-34.

55. Tseng $\mathrm{CH}$. Metformin use and cervical cancer risk in female patients with type 2 diabetes. Oncotarget. 2016;7:59548-55.

\section{Ready to submit your research? Choose BMC and benefit from:}

- fast, convenient online submission

- thorough peer review by experienced researchers in your field

- rapid publication on acceptance

- support for research data, including large and complex data types

- gold Open Access which fosters wider collaboration and increased citations

- maximum visibility for your research: over $100 \mathrm{M}$ website views per year

At BMC, research is always in progress.

Learn more biomedcentral.com/submissions 